\title{
The Potential of Cultural Tourism and Use It in the Surkhandarya Region in Practice
}

\author{
Surayyo Yuldashevna Pulatova \\ Lecturer at the Department of "Tourism and Hotel Industry", Termez State University
}

\begin{abstract}
The article examines the role of cultural tourism in the socio-economic development of the Surkhandarya region. The main problems of development and formation of the existing tourist destination in the Surkhan oasis are analyzed.
\end{abstract}

KEYWORDS: touristic activity, attracting tourists, cultural tourism, cultural and historical potential, touristic infrastructure.

\section{INTRODUCTION}

Tourism is inextricably linked with all sectors of the economy and its function is impossible without them. Accordingly, the development of tourism involves the entire complex of the economy and the development of the infrastructure of the territory.

At the present stage, cultural tourism takes the leading place among the main types of tourism.

Stimulating the tourism sector as a factor in the development of the region can lead to an intensification of investment processes, promoting an increase in human potential, smoothing out socio-economic inequality, creating new job opportunities, increasing employment and living standards of the population, as well as reducing population migration. In addition, the functioning and development of the tourism industry stimulates the development of related sectors of the region's economy.

Questions of a theoretical and methodological nature on the problems of researching the sphere of cultural tourism are reflected in the works of Russian and foreign scientists. However, these works are mainly of a theoretical or methodological nature, which is certainly important and useful, but does not always make it possible to apply their results in the practical activities of both government agencies and private enterprises for the development of the tourism sector in the region.

A significant number of scientific works are devoted to the regional aspects of the development of cultural tourism.

\section{RESEARCH METHODOLOGY}

As a result of the study, problems were identified related to the factors in the development of cultural tourism. During the study, methods such as deduction, comparative analysis, synthesis, etc. were used. Tabular and graphical presentation of analytical information speaks of the validity and reliability of the research results.

\section{ANALYSIS AND RESULTS}

To determine the current state and identify basic problems in the field of tourism, an analysis was carried out in the Surkhandarya region.

One of the main indicators of the functioning of the tourism industry is the size of the tourist flow, which will determine the main characteristics that form the characteristics of the average tourist visiting the Surkhandarya region.

Table 1. Information about tourists who visited the Surkhandarya region ${ }^{1}$

\begin{tabular}{|c|c|c|c|c|c|c|c|}
\hline \multirow[b]{2}{*}{ Indicators } & \multirow[b]{2}{*}{2015} & \multirow[b]{2}{*}{2016} & \multirow[b]{2}{*}{2017} & \multirow[b]{2}{*}{2018} & \multirow{2}{*}{$\begin{array}{l}2019 \text { (according } \\
\text { to December } 1 \text { ) }\end{array}$} & \multicolumn{2}{|l|}{2015 to 2019} \\
\hline & & & & & & $\begin{array}{l}\text { The absolute increase } \\
\text { in tourists, per. }\end{array}$ & $\%$ \\
\hline Number of tourists, of which: & 42051 & 49986 & 58318 & 82350 & 621556 & 579505 & 6,8 \\
\hline - the number of foreign tourists, per. & 7462 & 8052 & 9754 & 32050 & 119756 & 112294 & 6,3 \\
\hline - the number of local tourists, per. & 34589 & 41934 & 48564 & 50300 & 501800 & 467211 & 6,2 \\
\hline
\end{tabular}

\footnotetext{
${ }^{1}$ Information of the Territorial Administration of the State Committee for Tourism Development of the Surkhandarya Region 
According to information from public accommodation, tourist organizations, museums and other exhibition objects, the total tourist flow in the Surkhandarya region for the period from 2015 to 2019 (according to December 1) increased almost 13.8 times and amounted to 621,556 people. Of which, this year 119,756 foreign tourists from 114 countries visited the region, which is 3.7 times more than in the same period last year. The number of local tourists this year amounted to 501,800, which has increased 10 times compared to last year.

Another important indicator of tourism development in the region is the provision of public accommodation facilities.

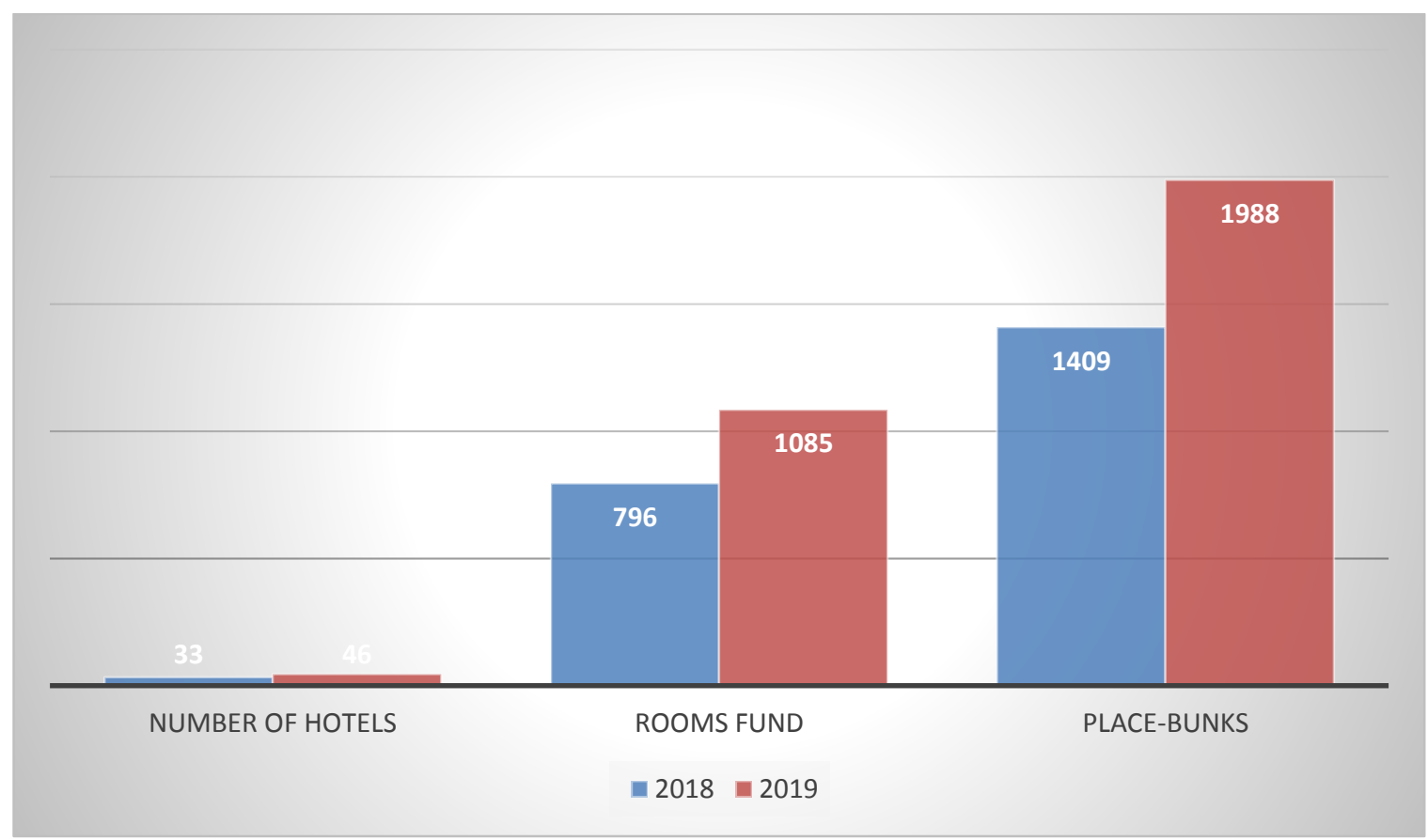

Pic.1. Hotel activity indicators in Surkhandarya region.

As can be seen in Figure 1, the total number of hotels during the study period increased by 13 units and amounted to 46 units, with 1085 rooms with a total capacity of 1.9 thousand beds. The number of rooms provided by hotels has increased by $3 \%$ compared to the previous year.

In addition, one of the problems affecting the development of cultural tourism in the region is the unsatisfactory state of the transport networks, which does not have high-quality coverage in most areas. This fact reduces the transport accessibility of tourists to the sights of the region. For example, in the region, according to the compiled list of cultural heritage sites to visit, out of 76 sites, only 25 sites are offered as places to visit for tourists. In addition, among the established road signs at 76 tourist sites in the region, 45 are old-style road signs.

As you know, the success of any region in the market of tourist services depends primarily on its attractiveness (the presence in the region of a combination of historical, cultural, natural, climatic and socio-economic objects and conditions).

The presence of such cultural and historical monuments represents a huge cultural potential for the favorable development of cultural and educational tourism in the region. Currently, 561 units of cultural heritage objects are registered. 30 units of the total number of historical and cultural monuments are architectural objects, 45 units are archaeological objects, 39 units of monumental art. The most visited place by tourists is the city of Termez. Basically, tourists come to Termez to inspect the ancient settlement of Old Termez, the highly revered mausoleum-mazar of the Muslim saint Hakim At-Termizi, the ruins of the Kara-Tepe Buddhist monastery, the Kyrk-Kyz palace, the Kokildor khanaki and the complex of mausoleums of local rulers Sultan-Saodat. In addition, all significant tourist sites of the city are located on the central street of the city of Hakim AtTermizi. These are the Termez Archaeological Museum, the Palace of Arts with attractions, the Clock Tower, the bazaar, the Surkhan Hotel, the Surkhandarya Regional Administration which is called by inhabitants as "Hokimyat", the "Bolajon" Park, the 19th century Russian garrison fortress and the Russian Church of St. Prince Alexander Nevsky, Shark hotels and "Ulugbek", "Friendship of peoples" bridge, etc.

According to international experts, over the past ten years, one of the most developing types of cultural tourism is event tourism. Event tourism allows you to use the tourism opportunities of the region as efficiently as possible, combining permanent (museums, monuments, religious buildings, natural attractions, historical sites) and temporary (cultural, sports and musical attractions) tourist attractions into a tourist product.

I would like to note that the Surkhandarya region is becoming a permanent venue for music folklore festivals at 
the international level, which contributes to the development of cultural event tourism in the region. Every year, in the Boysun district of the Surkhandarya region, an international folklore festival "Boysun spring" is held.

At the present stage, the development of educational (children and youth) tourism has particular relevance. The region has developed a cycle of cultural tourism programs for schoolchildren and students "Travel in five directions", which is a set of tourist routes (Kokildor ota, Kyrk kyz, Sultan Saodat, Fayaz-Tepe and Hakim At-Termizi).

\section{CONCLUSION}

Thus, the analysis of the state of development of the tourism sector of the Surkhandarya region allows us to highlight the main directions and ways of developing cultural tourism in the Surkhandarya region:

- promotion of the national tourism product in the domestic market;

- organization of excursion trips for students of educational institutions in order to learn about history and culture;

- support and development of traditional folk crafts;

- popularization and development of children's and youth cultural and enlightening tourism;

\section{REFERENCES}

1. Izotova M.A., Matyukhina Yu.A. Innovations in socio-cultural service and tourism. Scientific book. 2009. P.-3

2. Chelnokova, E.A. Agaev, Korovina E.A., Somova N.M. Event tourism of the Nizhny Novgorod region. Basic research. - 2016. - No. 6 (part 2) - P. 484-488

3. Kalnei V.A., Sholokhova V.V. The role of event tourism in the development of the region. RMAT Bulletin No. 1 (4), 2012 P.24

4. Stepanova S.V. The tourist resource of borders: the potential of the border regions of the North-West of Russia // Baltic region. 2017. Vol.9, No. 2. S.105121. doi: 10.5922 / 2074-9848-2017-2-6.

5. Semyonova L.V. "The influence of transport links on the competitiveness of the tourism industry in the Kaliningrad region" Service in Russia and abroad, vol.10.no.3 (64), p.147-158

6. Golibjon, Y. (2016). Innovation and SME Development: Indonesian Experience in Uzbekistan Context. Journal of Entrepreneurship \& Organization Management, 5: 3.

DOI: $10.4172 / 2169-026 \mathrm{X}, 1000198$. 